\title{
The Conglomerate Discount in Germany and the Relationship to Corporate Governance
}

\author{
Christian Weiner*
}

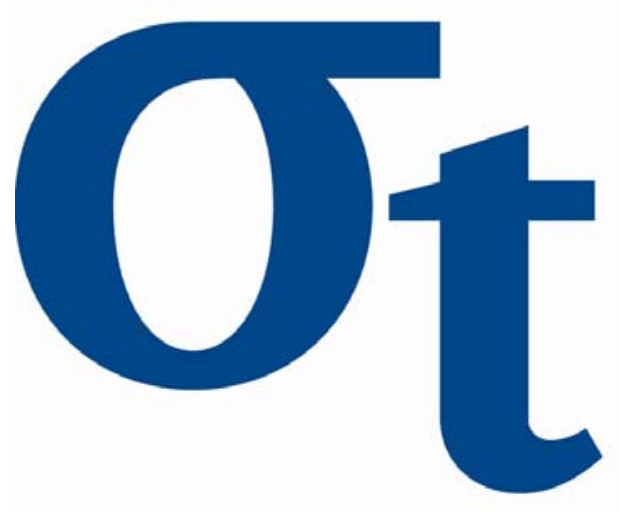

* School of Business and Economics, Humboldt-Universität zu Berlin, Germany
This research was supported by the Deutsche Forschungsgemeinschaft through the SFB 649 "Economic Risk".

http://sfb649. wiwi. hu-berlin.de ISSN 1860-5664

SFB 649, Humboldt-Universität zu Berlin

Spandauer Straße 1, D-10178 Berlin
D)

$\nabla$

6

m

는 


\title{
The Conglomerate Discount in Germany and the Relationship to Corporate Governance*
}

\author{
Christian Weiner ${ }^{\dagger}$
}

December 14, 2005

\begin{abstract}
This paper documents the conglomerate discount for all available German firms and the DAX 30 firms in detail. It shows a moderate discount of about 0.06 based on German comparable firms and of about 0.20 for a combined sample of German and European peer groups. I further examine the relationship between the discount and industry concentration as well as uncertainty of valuation. Finally, I document that corporate governance behavior affects the conglomerate discount.
\end{abstract}

*I would like to thank Ernst Maug, Ingolf Dittmann, Oliver Spalt, Daniel Klein and Niels Ulbricht for helpful discussions and comments. I gratefully acknowledge support by the Rudolf von Bennigsen-Foerder foundation and the Deutsche Forschungsgemeinschaft through the SFB 649 "Economic Risk".

${ }^{\dagger}$ Humboldt-Universität zu Berlin, School of Business and Economics, Spandauer Str. 1, 10178 Berlin, Germany; e-mail: weiner@wiwi.hu-berlin.de 


\section{Introduction}

In this paper I examine whether there exists a diversification discount or a premium in Germany, discuss several reasons for the results and investigate the relationship between the diversification discount and corporate governance behavior. This empirical work covers all publicly traded German companies that are available in the Worldscope database between 1991 and 2003. I also investigate the largest German companies in detail.

This paper provides a comprehensive analysis of the diversification discount in Germany and relates this topic to corporate governance behavior. The main contribution of this work can be summarized by the following three points:

First, I document that the existing papers and the underlying procedures for the valuation of diversified firms are biased due to measurement errors and provide too high excess values. Therefore, the applied method uses another measure to get unbiased valuation results.

Second, I consider two sets of peer groups, one with pure German firms and one with German and European firms for the valuation process, to avoid a general overor undervaluation of German firms. In this context I also give a detailed description how diversification affects the value of the 30 largest firms in Germany. Finally, I discuss how valuation uncertainty and diversification trends affect the conglomerate discount over time.

Third, I document how a potential conglomerate discount is related to corporate governance developments. The idea is that a positive corporate governance behavior overcomes several causes that lead to a conglomerate discount. To do so, I perform a regression analysis with a corporate governance rating for all DAX 30 companies and the conglomerate discount values from the previous analysis.

The results of this paper indicate that firms in Germany will be traded at a valuation discount of about $3 \%$ to $10 \%$ on average if one uses the standard methods provided by Berger and Ofek (1995) as well as subsequent authors and at an average valuation discount of $21 \%$ to $23 \%$ if one uses comparable companies from a combined German and European sample. These are significant differences that are only caused 
by methodical discrepancies but not by fundamental changes. The valuation results of the largest 30 firms in Germany (selected from the DAX 30 index) show that diversification discounts or premiums can be associated with industry membership. For instance, most firms in the chemical and pharmaceutical industry trade at a valuation discount, while firms in the technology and telecommunication industry trade at a valuation premium. These results are robust over time. I also provide evidence that higher uncertainties in valuation - measured as within peer group variation - are associated with lower valuation accuracy, and also that an increasing diversification over time leads to higher discounts on average.

I also test whether there exists a relationship between the conglomerate discount and corporate governance behavior and show that a positive corporate governance behavior of a company reduces the diversification discount or turns the discount into a premium. Possible arguments for these findings are that a decline of agency costs is associated with conglomerate firm structures. Some determinants to explain the conglomerate discount are agency costs arising from ineffective internal capital markets, suboptimal incentive compensation for managers, information asymmetries between segment managers and increased incentive for rent seeking by managers. A well-established corporate governance is a possible way to reduce these deficits and also the discount of the company.

The idea that companies with several business segments trade at a discount compared to their single-segment counterparts remains a well established result in financial research. For instance, Lang and Stulz (1994) as well as Berger and Ofek (1995) show that the discount for U.S. companies ranges between $13 \%$ and $54 \%$ depending on the valuation method. Recent papers by Campa and Kedia (2002) as well as Graham et al. (2002) show that there exists a strong selection bias which causes a large fraction of the discount. Schoar (2002) and Villalonga (2004a) use establishmentlevel data to value diversified companies. They present evidence that the discount can be reduced or turns into a premium if more detailed company data are used. There exists only few research that documents a discount for other countries than the United States. Lins and Servaes (1999) find a discount for Japan and the United 
Kingdom of about $10 \%$ and $15 \%$, respectively, while they are not able to determine a discount for German firms. Schwetzler and Reimund (2003) present an average discount of about $6 \%$ for Germany. Altogether, most researchers see negative impacts of diversification on market value but the results cover a wide range and seem to be quite ambiguous.

There is widespread research about corporate governance and the effects of corporate governance behavior on company values. Papers from Drobetz, Schillhofer and Zimmermann (2003), Bauer, Gunster and Otten (2004) or Black (2001) document that corporate governance is of relevance for the firm value. On the other hand there is no paper that documents a significant relationship between corporate governance and the conglomerate discount.

This paper has the following structure: in section 2 the related literature of the conglomerate discount and diversification will be discussed. Section 3 presents the dataset. Section 4 documents the diversification discount for all available German firms from 1991 to 2003, and for the 30 largest firms in detail. Section 5 presents reasons for the conglomerate discount and shows the relationship between excess value and several explanatory variables. Section 6 relates the diversification discount to corporate governance behavior. Section 7 concludes.

\section{Related Literature}

There exists a comprehensive literature about the diversification discount. The idea that diversified firms have a lower value than the sum of their segments dates back to the empirical observations of Lang and Stulz (1994) as well as Berger and Ofek (1995). They provide evidence that the discount of U.S. firms compared to their singlesegment counterparts in the same industry ranges between $13 \%$ and $54 \%$ depending on the valuation multiple and the year considered. Typical multiples in this context are firm value to sales, firm value to assets, firm value to EBIT and Tobin's q. Servaes (1996) supports the findings of the previous literature. He covers an earlier period from 1961 to 1976 and calculates significant conglomerate discounts especially in the 
1970s. His results are robust to differences in industry-adjustments and additional control variables like size as well as variables that measure financial constraints. Schoar (2002) and Villalonga (2004a) use the common valuation methodology but other than the standard data sources provided by Compustat. Villalonga compares BITS (Business Information Tracking Series) and Compustat data for firms in the United States and shows that the first data source provides a conglomerate premium while the latter a valuation discount. The premium is robust both over time and with respect to different control variables.

Summarized, I find that all investigations use similar valuation approaches, datasets and multiples. The typical multiples are based on sales, assets, EBIT or Tobin's q, the averaging method uses mean or median and typical excess values are calculated by using the natural logarithm of the ratio between the observed market value and the imputed value.

There are only few papers that consider other countries than the U.S. to document the conglomerate discount. Lins and Servaes (1999) investigate firms in Japan, the United Kingdom and Germany. They find a discount of $10 \%$ for Japanese and of $15 \%$ for British firms, while there is no discount for German firms. Due to deficits of their database they only use sales multiples. They explain the non-existence of a discount in Germany with the concentrated ownership structure of insiders that leads to higher firm values. Another paper from Lins and Servaes (2002) investigates seven emerging market countries. They find that the diversification discount is about $7 \%$ on average. They explain the discount with a lower profitability of diversified firms, a membership of industrial groups and a management ownership concentration between $10 \%$ and 30\%. Fauver, Houston and Naranjo (2002) cover 8,000 companies from 35 countries and find that the conglomerate discount is negatively related to the level of capital market integration and development. They also provide evidence that a country's legal system and the ownership structure of the firm affect the value of diversified firms. Schwetzler and Reimund (2003) show that cash holdings of diversified firms lead to biased results. After deducting cash from the firm value the average discount is about $6 \%$. Overall, the discount for countries outside the United States ranges 
between $5 \%$ and $15 \%$.

\section{Data Selection}

This study uses market and accounting data from the Thomson Financial Worldscope database. For the investigations I require three datasets. The first contains all German multi-segment firms, the second contains all German single-segment firms and the third contains all German and European single-segment firms. Here, European firms are drawn from Austria, Belgium, Finland, France, Germany, Greece, Ireland, Italy, Luxembourg, Netherlands, Portugal, and Spain (Euro countries). The sample datasets cover data from all years between 1991 and 2003. I do not exclude financial firms because a significant fraction of German firms operates in the financial industry or contains segments in this industry. I also provide summarized results for datasets without financial companies to show that financial companies do not produce deviating figures. All three datasets have the following restrictions: market price, number of shares, net sales, total debt and total assets have to be available for each firm and each year. Information about net sales, assets and industry membership based on SIC-codes for at least one industry segment have to be available. The sum of segment sales has to be within $1 \%$ of net sales of the whole firm. $5.6 \%$ of the observations in 2002 show deviations of more than $1 \%$ which is a secondary problem. For assets the quantity of observations that exceeds $1 \%$ is $58.4 \%$. Together with the fact that I have less segment information for assets than for sales I would lose too many observations to produce reliable results. Therefore, I scale the current asset value A of segment i to the new assets value for one specific firm $\mathrm{f}$ in the following way:

$$
A_{i, f, \text { new }}=\left(\frac{\text { total assets } f}{\sum_{j=1}^{S E G_{f}} A_{j, f}}\right) * A_{i, f, \text { old }},
$$

where $\left(\frac{\text { total assets }}{\sum_{j=1}^{S E G_{f}} A_{j, f}}\right)$ is the scaling factor, and $S E G_{f}$ is the number of segments for firm $\mathrm{f}$. The ratio of total assets and the sum of segment assets for one firm will be multiplied with each segment. Finally, the sum of the scaled segment assets is equal 
to total assets. This procedure results in a dataset of 3,228 firm-years for German multi-segment firms, 3,080 firm-years for German single-segment firms and 27,492 firm-years for European single-segment firms.

Table 1 presents the descriptive statistics of German multi-segment firms and German and European single-segment firms that I need for the analysis. I identify conglomerates if they have more than one segment based on the 2-digit SIC-code and stand-alone firms if they have only one segment. Panel A contains all firms that are listed in Germany and have more than one segment. The results are separated for each year from 1995 to 2003. The years 1991 to 1994 show similar results as in 1995 and are therefore suppressed.

The number of multi-segment firms increases over the years from 227 in 1995 to 402 in 2003, i.e. more conglomerates operate in the market. The figures for total assets and sales also show an increase. Mean assets double from 1995 to 2000. In 2003 mean asset values are 5 times higher than in 1995. The standard deviation also shows a sharp increase from 1995 to 2003. Sales values also increase significantly from 1995 to 2003 but the growth rate is much lower compared to assets growth. Mean sales increase by about $40 \%$. There is also a slight increase in the average number of segments from 3.74 to 4.11 . This trend to more diversification has also been documented by other researchers ${ }^{1}$.

Panel B comprises all firms that have only one industry segment. I use this dataset to select and create peer groups for the estimation of segment values of Panel A's conglomerates. The number of firms increases from 236 to 302 over the years. This is less than in Panel A. The reason is that the propensity to diversify increases. I am able to find more firms that diversify their business than firms that concentrate their business. Thus, several firms shift from Panel B to Panel A over the years. While the overall number of firms that are listed in Germany increases strongly, the number of single-segment firms increases less, and there is also a significant number of firms that expands the number of business segments. Mean assets and mean sales are almost constant over time for single-segment firms. Assets only increase by about

\footnotetext{
${ }^{1}$ See for instance Servaes (1996), Lins and Servaes (1999).
} 
Table 1: Descriptive statistics of German and European firms

This table displays descriptive statistics for the underlying datasets from 1995 to 2003. Data from 1991 to 1994 show similar statistics and are therefore suppressed. In panel A only firms are covered that have more than one segment and are located in Germany. In panel B all firms with exactly one segment and German location are presented. In panel $\mathrm{C}$ all European firms with one segment are displayed. All assets and sales values are converted to Euro and in billions. Segment information are based on 2-digit SIClevels. Std refers to standard deviation, obs. counts the number of firms per year. The right-most column presents the mean number of segments.

\begin{tabular}{|c|c|c|c|c|c|c|c|c|c|c|}
\hline \multirow[t]{2}{*}{ year } & \multirow[t]{2}{*}{ obs. } & \multicolumn{4}{|c|}{ assets } & \multicolumn{4}{|c|}{ sales } & \multirow{2}{*}{$\begin{array}{c}\text { SEG } \\
\text { mean }\end{array}$} \\
\hline & & $\min$ & mean & $\max$ & std & $\min$ & mean & $\max$ & std & \\
\hline \multicolumn{11}{|c|}{ Panel A: German multi-segment firms } \\
\hline 1995 & 227 & 0.00 & 3.96 & 366.33 & 25.11 & 0.00 & 2.74 & 52.94 & 6.97 & 3.74 \\
\hline 1996 & 243 & 0.00 & 4.52 & 450.34 & 30.12 & 0.00 & 2.77 & 54.37 & 7.46 & 3.63 \\
\hline 1997 & 250 & 0.00 & 5.17 & 530.36 & 34.62 & 0.00 & 3.08 & 63.43 & 8.77 & 3.70 \\
\hline 1998 & 262 & 0.00 & 6.03 & 621.14 & 40.37 & 0.00 & 3.50 & 131.78 & 11.86 & 3.61 \\
\hline 1999 & 305 & 0.00 & 6.79 & 822.87 & 49.45 & 0.00 & 3.20 & 149.99 & 12.31 & 3.53 \\
\hline 2000 & 341 & 0.00 & 7.44 & 693.70 & 47.07 & 0.00 & 3.56 & 162.38 & 13.62 & 3.70 \\
\hline 2001 & 394 & 0.00 & 10.25 & 914.38 & 68.55 & 0.00 & 3.67 & 152.87 & 13.62 & 3.71 \\
\hline 2002 & 404 & 0.00 & 10.33 & 810.38 & 62.40 & 0.00 & 3.45 & 149.58 & 12.79 & 3.98 \\
\hline 2003 & 402 & 0.00 & 19.59 & 896.49 & 91.69 & 0.00 & 3.00 & 136.44 & 16.65 & 4.11 \\
\hline \multicolumn{11}{|c|}{ Panel B: German single-segment firms } \\
\hline 1995 & 236 & 0.00 & 8.00 & 246.85 & 29.84 & 0.00 & 1.47 & 45.05 & 4.65 & 1 \\
\hline 1996 & 268 & 0.00 & 8.04 & 286.17 & 31.84 & 0.00 & 1.40 & 51.19 & 4.79 & 1 \\
\hline 1997 & 274 & 0.00 & 8.97 & 345.32 & 36.64 & 0.00 & 1.49 & 51.02 & 4.61 & 1 \\
\hline 1998 & 304 & 0.00 & 9.42 & 446.93 & 45.37 & 0.00 & 1.46 & 57.98 & 5.17 & 1 \\
\hline 1999 & 333 & 0.00 & 9.63 & 482.11 & 48.14 & 0.00 & 1.44 & 69.06 & 5.25 & 1 \\
\hline 2000 & 313 & 0.00 & 8.44 & 925.79 & 65.44 & 0.00 & 1.14 & 73.22 & 5.40 & 1 \\
\hline 2001 & 315 & 0.00 & 7.56 & 697.10 & 56.69 & 0.00 & 0.90 & 44.15 & 3.65 & 1 \\
\hline 2002 & 280 & 0.00 & 5.47 & 671.50 & 43.66 & 0.00 & 0.68 & 38.57 & 2.85 & 1 \\
\hline 2003 & 302 & 0.00 & 9.91 & 469.38 & 51.31 & 0.00 & 1.10 & 24.01 & 3.27 & 1 \\
\hline \multicolumn{11}{|c|}{ Panel C: German and European single-segment firms } \\
\hline 1995 & 2036 & 0.00 & 7.56 & 253.50 & 27.73 & 0.00 & 1.22 & 45.05 & 3.52 & 1 \\
\hline 1996 & 2376 & 0.00 & 7.43 & 351.00 & 29.85 & 0.00 & 1.12 & 51.19 & 3.55 & 1 \\
\hline 1997 & 2550 & 0.00 & 7.78 & 379.56 & 32.46 & 0.00 & 1.13 & 51.02 & 3.45 & 1 \\
\hline 1998 & 2660 & 0.00 & 7.57 & 446.93 & 35.96 & 0.00 & 1.14 & 57.98 & 3.90 & 1 \\
\hline 1999 & 2658 & 0.00 & 8.86 & 696.97 & 43.82 & 0.00 & 1.18 & 69.06 & 4.19 & 1 \\
\hline 2000 & 2469 & 0.00 & 7.97 & 925.79 & 51.68 & 0.00 & 1.23 & 73.22 & 5.31 & 1 \\
\hline 2001 & 2367 & 0.00 & 6.55 & 824.26 & 48.97 & 0.00 & 0.90 & 54.87 & 3.70 & 1 \\
\hline 2002 & 2130 & 0.00 & 6.53 & 709.33 & 44.64 & 0.00 & 0.80 & 45.45 & 3.23 & 1 \\
\hline 2003 & 2225 & 0.00 & 11.23 & 559.24 & 52.58 & 0.00 & 1.22 & 34.65 & 3.58 & 1 \\
\hline
\end{tabular}


25\%, while sales decrease from 1.47 to 1.10 . If I compare Panel A and Panel B one can see a clear pattern. In 1995 mean assets for single-segment firms are twice as much as for conglomerates, while in 2003 the values are the other way around. Sales for single-segment firms in 1995 are about 50\% of multi-segment firms. This ratio decreases to $18.3 \%$. So one can see that there is a strong increase in sales and assets for multi-segment firms, while single-segment firms almost stay constant.

Panel C displays all European and German firms with one segment. This dataset will also be used for segment valuation purposes. I detect an increase in the number of firms from 1995 to 1999 by about 30\%. Then the number decreases. In 2003 it is almost equal to 1995. The mean assets in 2003 are about 50\% higher than in 1995, while sales are almost equal.

I will not only document the conglomerate discount for all German firms on average but also for the largest 30 firms in Germany in detail. Table 2 shows the descriptive statistics for all German firms that are a member of the DAX 30 in 2004. Data are from Worldscope for the year 2002. The table displays sales, assets and enterprise value from the balance sheet as well as the number of segments and the primary SIC-code.

There exist 6 firms (Allianz, HVB, Commerzbank, Deutsche Bank, Deutsche Boerse, Muenchener Rück) that operate in the financial industry. 3 are retail banks, 2 are insurance firms and one is a stock exchange. The sales and assets figures are extraordinary high, which is a typical characteristic of firms within that industry. Only Deutsche Boerse is different because the main operations are transaction services. All firms except HVB have between 5 and 7 segments and are aligned to the same 1-digit SIC-code. There are also 6 firms (Altana, BASF, Bayer, Fresenius, Henkel, Schering) in the chemical or pharmaceutical industry. BASF and Bayer are about 3 to 4 times larger than the other firms. Altana and Fresenius have only one segment, while the other firms cover between 5 and 7 segments. There exist 4 firms (BMW, Continental, DaimlerChrysler, Volkswagen) that operate in the automotive industry. While BMW, DaimlerChrysler and Volkswagen are car manufacturers, Continental is a car equipment supplier. The size of the firms is very inhomogeneous. The number 
Table 2: Descriptive statistics of DAX30 firms

This table displays descriptive statistics for all firms that are listed in the German DAX 30 index for the year 2004. Data are from Worldscope for the year 2002. Sales is net sales, ta is total assets, ev is enterprise value, evsa is enterprise value divided by net sales, evta is enterprise value divided by total assets, seg shows the number of segments based on the 2 -digit-SIC segment code, SIC is the primary SIC-code. All values are in millions and local currency. Firms are listed in alphabetic order.

\begin{tabular}{lrrrrrrr}
\hline name & \multicolumn{1}{c}{ sales } & \multicolumn{1}{c}{ ta } & \multicolumn{1}{c}{ ev } & evsa & evta & seg & SIC \\
\hline Adidas-Salomon & $6,523.41$ & $4,091.11$ & $5,264.68$ & 0.80 & 1.28 & 3 & 3149 \\
Allianz & $92,232.00$ & $810,378.00$ & $252,042.94$ & 2.73 & 0.31 & 5 & 6331 \\
Altana & $2,608.67$ & $2,200.61$ & $6,025.37$ & 2.31 & 2.73 & 1 & 2834 \\
BASF & $32,215.50$ & $33,881.60$ & $24,084.75$ & 0.74 & 0.71 & 7 & 2821 \\
Bayer & $28,958.00$ & $40,725.00$ & $24,765.83$ & 0.85 & 0.60 & 6 & 3089 \\
BMW & $42,282.00$ & $55,319.00$ & $45,765.48$ & 1.08 & 0.82 & 4 & 3711 \\
Commerzbank & $21,351.00$ & $416,843.00$ & $218,546.17$ & 10.23 & 0.52 & 7 & 6021 \\
Continental & $11,408.30$ & $7,933.10$ & $4,172.59$ & 0.36 & 0.52 & 5 & 3011 \\
DaimlerChrysler & $149,583.00$ & $186,194.00$ & $108,635.22$ & 0.72 & 0.58 & 5 & 3711 \\
Deutsche Bank & $56,029.00$ & $754,455.00$ & $232,038.12$ & 4.14 & 0.30 & 6 & 6021 \\
Deutsche Boerse & $1,170.90$ & $6,531.00$ & $7,805.30$ & 6.66 & 1.19 & 7 & 6231 \\
Dt. Lufthansa & $16,971.40$ & $18,956.80$ & $8,210.21$ & 0.48 & 0.43 & 6 & 4512 \\
Deutsche Post & $39,255.00$ & $161,201.00$ & $78,052.12$ & 1.98 & 0.48 & 5 & 4215 \\
Deutsche Telekom & $53,689.00$ & $125,814.00$ & $115,722.86$ & 2.15 & 0.92 & 5 & 4813 \\
E.ON & $36,126.00$ & $110,023.00$ & $50,300.92$ & 1.39 & 0.45 & 4 & 4931 \\
Fresenius & $5,349.08$ & $6,420.48$ & $6,120.77$ & 1.14 & 0.95 & 1 & 8071 \\
Henkel & $9,656.00$ & $8,187.00$ & $9,511.48$ & 0.98 & 1.16 & 5 & 2841 \\
HVB & $38,571.00$ & $671,499.00$ & $432,353.07$ & 11.20 & 0.64 & 1 & 6021 \\
Infineon & $5,207.00$ & $10,131.00$ & $5,765.48$ & 1.10 & 0.56 & 1 & 3674 \\
Linde & $8,726.00$ & $12,062.00$ & $7,468.17$ & 0.85 & 0.61 & 5 & 2813 \\
MAN & $16,040.00$ & $11,248.00$ & $3,478.92$ & 0.21 & 0.30 & 7 & 3711 \\
Metro & $51,526.00$ & $21,839.00$ & $13,103.11$ & 0.25 & 0.60 & 5 & 5149 \\
Muenchener Rk & $43,646.00$ & $182,144.00$ & $25,299.89$ & 0.58 & 0.13 & 6 & 6331 \\
RWE & $43,487.00$ & $92,680.00$ & $43,659.92$ & 1.00 & 0.47 & 8 & 4911 \\
SAP & $7,412.83$ & $5,353.98$ & $23,299.03$ & 3.14 & 4.35 & 5 & 7371 \\
Schering & $5,023.00$ & $5,392.00$ & $8,245.75$ & 1.64 & 1.52 & 5 & 2834 \\
Siemens & $84,016.00$ & $74,253.00$ & $42,572.50$ & 0.50 & 0.57 & 10 & 3661 \\
ThyssenKrupp & $36,698.00$ & $30,251.00$ & $11,213.53$ & 0.30 & 0.37 & 9 & 3312 \\
TUI & $20,302.40$ & $15,235.30$ & $8,651.01$ & 0.42 & 0.56 & 6 & 4725 \\
Volkswagen & $86,948.00$ & $107,488.00$ & $58,842.40$ & 0.67 & 0.54 & 2 & 3711 \\
\hline & & & & & & &
\end{tabular}


of segments ranges between 2 and 5 . All firms have the same 1-digit SIC-code. E.ON and RWE are utility firms. The financial figures are similar, while the number of segments for RWE is twice as much as for E.ON. 3 firms (Deutsche Telekom, Infineon, SAP) are classified in the technology and telecommunication industry. Deutsche Telekom is the only firm in the telecommunication industry. The other firms in this segment are much smaller. 2 firms are classified as transportation firms. These are Deutsche Lufthansa and Deutsche Post. The number of segments is equal but the size is different. Metro is the only firm that operates in the wholesale and retail industry, respectively. 4 firms (Linde, MAN, Siemens, ThyssenKrupp) operate in the manufacturing sector. All firms in this industry are highly diversified and have more than 5 segments. The dispersion of the firm size is also high. The last 2 remaining firms can be classified as consumer product suppliers. While Adidas-Salomon has only three segments, TUI as a former manufacturing firm has six segments. One can see that only 4 firms are single-segment firms, while the rest has 5 segments on average. The table also documents that large firms have more segments than small firms. For instance, all firms in the sample with one segment have sales below 6 billion Euros $^{2}$, while the firms with more than 6 segments have an average sales value that is close to 30 billion Euros. This is consistent with the previous table and the statistics of other authors ${ }^{3}$.

\section{The Conglomerate Discount for German Firms}

In this section I investigate whether there exists a conglomerate discount or a conglomerate premium for German firms on average. I cover a time period from 1991 to 2003. I calculate excess values by comparing the observed firm value and the imputed value, which is based on sales as well as assets multiples drawn from German and European single-segment firms. I also present detailed valuation and conglomerate results for the largest 30 firms in Germany based on the DAX 30 index put together

\footnotetext{
${ }^{2} \mathrm{HVB}$ is an exception due to the banking characteristics.

${ }^{3}$ See Servaes (1996). He shows that single-segment firms have median assets of 77.1 million $\$$, while multi-segment firms have median assets of 115.1 million \$. Berger and Ofek (1995) show that median sales are 116 million $\$$ for single-segment firms and 316 million $\$$ for multi-segment firms.
} 
in 2004 .

\subsection{Valuation Methodology}

To investigate value differences between single- and multi-segment firms, I apply the valuation methodology of Berger and Ofek (1995) but apply some modifications. Excess value is calculated by using the natural logarithm of the ratio of the observed enterprise value to the imputed enterprise value. Market value will be calculated by multiplying market value per share with the number of shares. Enterprise value is the sum of market value of equity and book value of total debt. The imputed value of the whole firm is the sum of the imputed values of all available segments based on 2-digit SIC-codes.

A segment's imputed value can be calculated by using the sales or assets value of the segment multiplied with either the arithmetic mean or median ratio of the firm value to the accounting item of an industry peer group or the geometric mean of that ratio. While the mean and the median ratios have been used by several authors, the geometric mean is a new measure. For instance, Lang and Stulz (1994), Servaes (1996) and Villalonga (2004a) use the arithmetic mean to average ratios from comparable companies. Berger and Ofek (1995), Lins and Servaes (1999), Campa and Kedia (2002), Mansi and Reeb (2002) as well as Graham, Lemmon and Wolf (2002) operate with the median of these ratios. Villalonga (2004b) uses median averaging for sales and assets multiples, while she applies arithmetic mean to Tobin's q. She shows that excess values ${ }^{4}$ based on Tobin's q are notably lower than on $\operatorname{assets}^{5}$, which is a remarkable result, because assets multipliers and Tobin's q follow a similar data definition. I discuss the averaging method for the peer group's sales or assets ratio that leads to the valuation multiple in detail, because Dittmann and Maug (2005) show that arithmetic mean averaging produces skewed results. This

\footnotetext{
${ }^{4}$ In this case excess value based on assets is the natural logarithm of the ratio of the firm's market value to its imputed value. A firm's imputed value is the sum of the imputed values of its segments, where a segment's value is equal to the segment's assets multiplied by its industry median ratio of market value to assets. Excess value based on q is the difference between firm's q and the asset-weighted average of the imputed q's of its segments, where a segment's imputed q is the industry average q.

${ }^{5}$ For instance excess value based on assets multiplier is -0.076 , while it is -0.174 for Tobin's q.
} 
means in the case of the conglomerate discount that the calculated excess values based on arithmetic mean averaging is too high. They further provide evidence that a logarithmic transformation before averaging or the use of geometric mean averaging procedures result in unbiased excess values and produce smaller discount values. Therefore, this paper uses and displays excess values based on the median and geometric mean averaging procedure.

The selection of peer group firms is also of critical importance. Therefore, I propose an algorithm used by Alford (1992) to identify comparable firms. I start with the 2-digit SIC code and select all single segment firms with the same code. If there are less than 5 firms then I use the 1-digit SIC code. If there are less than 5 firms on the 1-digit level then I use the whole market. For about $60 \%$ of the segments it is possible to identify comparable companies based on 2-digits. $30 \%$ can be matched on the 1-digit code.

\subsection{Empirical Results}

Table 3 documents the conglomerate discount for German firms from 1991 to 2003. I use the methodology proposed by Berger and Ofek (1995) with some differences. The averaging method for the combination is of critical importance. Therefore, each segment of a firm will be valued separately by multiplying the sales (assets) value with the median ratio between enterprise value and sales (assets) of the peer group. This valuation procedure is coherent with several other studies. As mentioned previously, this leads to an unbiased result, if I use median as the averaging method. Additionally, I perform the same procedure with geometric mean instead of median aggregation. The table reports for each year the mean and median excess value for sales and assets multipliers with median and geometric mean averaging calculation. In 1991 I have not enough information to calculate excess values based on asset multipliers.

I make an additional distinction between different peer group samples. In panel A I use only German firms with single-segments as peer groups to calculate excess values. The results are comparable to the findings of Lins and Servaes (1999). They 
calculate a marginal excess value of $1.1 \%$ in 1992 and 5.7\% in 1994. Schwetzler and Reimund (2003) find an excess value of about $6 \%$ for a pooled sample from 1988 to 2001 , while I calculate an excess value of $6 \%$ on average based on median averaging. In Panel B also European firms together with German firms will be considered. Dittmann and Weiner (2004) show that the selection of comparable firms from European countries improves valuation accuracy compared to the exclusive selection from the same country. This could lead to a biased result because a conglomerate discount could be entirely occur due to the fact that firms are generally undervalued in Germany. I therefore perform a robustness check and test whether German firms are undervalued in a European context. The firms will have no conglomerate discount and should therefore provide excess values close to zero if they are not undervalued. On the other hand if these firms are undervalued one should see significant excess values. Additional influences like different accounting standards may lead to deviations from the zero point but these differences should be minor. I calculate excess values for German single-segment firms based on European peer groups in Panel C. I test differences of means between single- and multi-segment excess values (Panel B and C) to get reliable results.

The overall results of the analysis show that there is a small diversification discount independently of the valuation method and the peer group sample selection. A closer look at the figures provides some further insights. Panel A documents a mean excess value over all years from -0.03 to -0.10 depending on the averaging and multiple valuation method. This range is also documented by Schwetzler and Reimund (2003). They cover German firms from 1988 to 2001 and document an excess value of about $6 \%$ on average. It can be seen that excess values differ significantly over time. In 1992 and 1994 I detect average discounts based on sales multiples between -0.04 and -0.05 which is coherent with the finding of Lins and Servaes (1999). Assets multiples provide much higher discounts for the two years. While excess values between 1992 and 1999 are relatively low, there is a significant increase from 2000 to 2002. The geometric mean averaging method provides results that are slightly below the median method. 
Table 3: Conglomerate discount for German firms

Excess value is calculated from 1991 to 2003 for all German firms. It is defined as the natural logarithm of the ratio between observed firm value and imputed value. The imputed value is the sum of the segment's imputed values. A segment's imputed value is the sales or assets value of the segment multiplied with either the median ratio of the firm value to the accounting item of an industry peer group or the geometric mean of that ratio. I determine peer groups at the 2-digit SIC level. Peer group companies have one segment. Panel A shows the results for conglomerates based on peer groups containing only German firms, panel B the results for conglomerates based on peer groups containing German and European firms, panel $\mathrm{C}$ the results for single-segment firms based on German and European firms. If the sum of segment assets deviates from total assets then segment assets are scaled to total assets with the observed proportion. If segment values are not available then excess value is not displayed. The significance of the difference between means of single- and multi-segment firms (Panel B and C) is assessed using a t-test. The last row (mean II) in panel A and B shows average results if financial firms are excluded.

Panel A: Conglomerates and German peer groups

\begin{tabular}{|c|c|c|c|c|c|c|c|c|}
\hline \multirow[t]{3}{*}{ year } & \multicolumn{4}{|c|}{ sales basis } & \multicolumn{4}{|c|}{ asset basis } \\
\hline & \multicolumn{2}{|c|}{ median } & \multicolumn{2}{|c|}{ geo. mean } & \multicolumn{2}{|c|}{ median } & \multicolumn{2}{|c|}{ geo. mean } \\
\hline & mean & med. & mean & med. & mean & med. & mean & med. \\
\hline 1991 & -0.24 & -0.28 & -0.25 & -0.30 & & & & \\
\hline 1992 & -0.04 & -0.17 & -0.13 & -0.21 & -0.21 & -0.21 & 0.15 & 0.15 \\
\hline 1993 & -0.00 & -0.13 & -0.12 & -0.20 & 0.17 & 0.17 & 0.33 & 0.33 \\
\hline 1994 & -0.05 & -0.04 & -0.08 & -0.16 & -0.13 & -0.11 & -0.10 & -0.11 \\
\hline 1995 & -0.05 & -0.16 & -0.17 & -0.25 & -0.29 & -0.26 & -0.27 & -0.34 \\
\hline 1996 & -0.13 & -0.16 & -0.16 & -0.17 & -0.10 & -0.12 & -0.12 & -0.15 \\
\hline 1997 & 0.10 & 0.01 & 0.04 & -0.05 & 0.00 & -0.10 & 0.00 & -0.10 \\
\hline 1998 & 0.03 & -0.05 & -0.05 & -0.14 & 0.06 & -0.14 & 0.06 & -0.11 \\
\hline 1999 & -0.04 & -0.09 & -0.24 & -0.31 & 0.01 & -0.06 & -0.10 & -0.20 \\
\hline 2000 & -0.11 & -0.22 & -0.22 & -0.37 & -0.03 & -0.12 & -0.09 & -0.23 \\
\hline 2001 & -0.16 & -0.29 & -0.16 & -0.29 & -0.19 & -0.25 & -0.16 & -0.25 \\
\hline 2002 & -0.08 & -0.19 & -0.08 & -0.21 & -0.08 & -0.16 & -0.05 & -0.14 \\
\hline 2003 & 0.22 & -0.04 & 0.29 & 0.01 & -0.08 & -0.10 & -0.06 & -0.17 \\
\hline mean & -0.06 & -0.15 & -0.10 & -0.20 & -0.07 & -0.12 & -0.03 & -0.11 \\
\hline mean II & -0.06 & -0.07 & -0.12 & -0.13 & -0.11 & -0.09 & -0.05 & -0.13 \\
\hline
\end{tabular}


Panel B: Conglomerates and European peer groups

\begin{tabular}{|c|c|c|c|c|c|c|}
\hline \multirow[t]{3}{*}{ year } & \multicolumn{3}{|c|}{ sales basis } & \multicolumn{3}{|c|}{ asset basis } \\
\hline & median & \multicolumn{2}{|c|}{ geo. mean } & \multicolumn{2}{|c|}{ median } & geo. mean \\
\hline & mean med. & mean & med. & mean & med. & mean med. \\
\hline 1991 & $-0.22 * * *-0.18$ & $-0.24 * *$ & $*-0.24$ & & & \\
\hline 1992 & $-0.28 * * *-0.29$ & $-0.30 * *$ & $*-0.33$ & $-0.40 *$ & $*-0.40$ & $-0.41 * * *-0.41$ \\
\hline 1993 & $-0.24 * * *-0.29$ & $-0.26 * *$ & $*-0.32$ & $-0.37 *$ & $*-0.37$ & $-0.29 * * *-0.29$ \\
\hline 1994 & $-0.28 * * *-0.34$ & $-0.30 * *$ & $*-0.38$ & $-0.27 *$ & $*-0.28$ & $-0.25 * * *-0.24$ \\
\hline 1995 & $-0.29 * * *-0.34$ & $-0.32 * *>$ & $*-0.39$ & $-0.38 *$ & $*-0.32$ & $-0.41 * * *-0.38$ \\
\hline 1996 & $-0.35 * * *-0.33$ & $-0.39 * *>$ & $*-0.43$ & -0.25 & -0.19 & $-0.26 * \quad-0.22$ \\
\hline 1997 & $-0.33 * * *-0.37$ & $-0.33 * *>$ & $*-0.38$ & -0.13 & -0.04 & $-0.17 * \quad-0.07$ \\
\hline 1998 & $-0.10 * *-0.22$ & $-0.13 * *$ & -0.27 & 0.04 & -0.14 & $0.01 * *-0.21$ \\
\hline 1999 & $-0.23 * * *-0.19$ & $-0.24 * *$ & $*-0.32$ & -0.10 & -0.08 & -0.13 \\
\hline 2000 & $-0.19 \quad-0.27$ & -0.28 & $-0.39 *$ & -0.06 & -0.07 & $-0.14 * \quad-0.18$ \\
\hline 2001 & $-0.29 * *-0.37$ & -0.36 & $-0.44 *$ & $-0.22 *$ & $*-0.23$ & $-0.24 * * *-0.28$ \\
\hline 2002 & -0.25 & -0.29 & -0.39 & $-0.25 *$ & $*-0.20$ & $-0.25 * * *-0.24$ \\
\hline 2003 & -0.17 & -0.03 & -0.23 & $-0.12 *$ & -0.12 & $-0.15 * * \quad-0.19$ \\
\hline mean & $-0.23 * * *-0.28$ & $-0.27 * *$ & -0.35 & $-0.21 *$ & $*-0.20$ & $-0.23 * * *-0.24$ \\
\hline mean II & -0.14 & -0.22 & -0.21 & -0.20 & -0.15 & -0.18 \\
\hline
\end{tabular}


Panel C: Single-segment firms and European peer groups

\begin{tabular}{|c|c|c|c|c|c|c|c|c|}
\hline \multirow[t]{3}{*}{ year } & \multicolumn{4}{|c|}{ sales basis } & \multicolumn{4}{|c|}{ asset basis } \\
\hline & \multicolumn{2}{|c|}{ median } & \multicolumn{2}{|c|}{ geo. mean } & \multicolumn{2}{|c|}{ median } & \multicolumn{2}{|c|}{ geo. mean } \\
\hline & mean & med. & mean & med. & mean & med. & mean & med. \\
\hline 1991 & 0.08 & 0.06 & 0.05 & 0.04 & 0.24 & 0.28 & 0.21 & 0.29 \\
\hline 1992 & -0.03 & -0.01 & -0.04 & -0.07 & 0.14 & 0.09 & 0.09 & 0.11 \\
\hline 1993 & -0.02 & -0.04 & -0.03 & -0.06 & 0.15 & 0.05 & 0.12 & 0.10 \\
\hline 1994 & -0.02 & 0.00 & -0.01 & -0.05 & 0.16 & 0.08 & 0.12 & 0.08 \\
\hline 1995 & 0.07 & -0.08 & 0.06 & -0.16 & 0.01 & 0.00 & -0.01 & -0.02 \\
\hline 1996 & 0.00 & -0.11 & -0.03 & -0.21 & -0.03 & -0.05 & -0.06 & -0.06 \\
\hline 1997 & -0.06 & -0.09 & -0.07 & -0.16 & -0.06 & -0.01 & -0.09 & -0.06 \\
\hline 1998 & 0.09 & -0.04 & 0.05 & -0.12 & -0.09 & -0.01 & -0.14 & -0.09 \\
\hline 1999 & 0.17 & -0.05 & 0.07 & -0.16 & 0.00 & -0.05 & -0.04 & -0.14 \\
\hline 2000 & -0.07 & -0.12 & -0.16 & -0.25 & -0.05 & -0.10 & -0.13 & -0.22 \\
\hline 2001 & -0.14 & -0.20 & -0.22 & -0.30 & 0.17 & 0.11 & 0.12 & 0.07 \\
\hline 2002 & -0.13 & -0.21 & -0.22 & -0.30 & 0.02 & 0.00 & -0.01 & -0.02 \\
\hline 2003 & -0.07 & -0.22 & -0.10 & -0.25 & 0.03 & -0.03 & 0.00 & -0.09 \\
\hline mean & -0.01 & -0.09 & -0.05 & -0.16 & 0.05 & 0.03 & 0.01 & 0.00 \\
\hline
\end{tabular}


Panel B documents excess values if I use a combination of German and European single-segment companies as peer groups but the same valuation methodology. Compared to the valuation results of panel A I find significantly higher excess values for almost all years, which is an interesting result that might has different reasons. The average excess values over all years are also significantly higher independently of the averaging method or the multiple type. One possible reason for these results could be the fact that the number of comparable single-segment companies is lower in panel A. The average number of comparable companies over all segments, firms and years in panel $\mathrm{A}$ is about 9 , while the average peer group size in panel $\mathrm{B}$ is about 2.5 times higher. Dittmann and Maug (2005) show that the peer group size is of critical importance for the provided valuation results. I am not able to conclude that the results of table $\mathrm{B}$ are caused by a generic undervaluation of conglomerates. It could also be a possible explanation that German firms always trade at a discount on average.

Therefore in panel C, I perform the same calculation as in panel B for all singlesegment firms available in Germany. I compare the observed market value of these firms with the estimated value based on German and European peer group selection. I show that there is almost no discount on average over all years. This indicates that there is no general discount for German firms. I document this by using standard T-tests.

The results do not differ substantially if I exclude financial companies from the datasets. The average results over all years in panel A and B (mean II) deviate by about 0.04 on average from the results with financial companies (mean).

Table 4 documents the conglomerate discount for each firm that is a member of the DAX 30 index in 2004. I show the results for two representative years (1996, 2002). I use the same methodology as in the previous analysis for all German firms. In Panel A of table 4 a peer group is selected from all German firms with only one business segment that have the same 2-digit SIC-code as the valued segment. If there are less than 5 peer group members then the 1-digit SIC-code is considered. Other 
reseachers ${ }^{6}$ identify conglomerates with 3 - or 4-digit SIC-codes. I see no significant differences for the DAX 30 firms if I consider these definitions and therefore omit the results. Panel B shows the results when peer firms are not only from Germany but additionally from a European group of companies. The sum of all imputed segment values leads to the imputed value of the firm. The deviation between the real value and the imputed value is measured by the natural logarithm of the ratio of these two figures. To reduce complexity two representative years are displayed. If I am not able to calculate an excess value or the firm is not listed in the specific year, then no value is displayed.

Table 4 reveals that firms in some industries trade at a discount while other trade at a premium. The six firms in the financial industry provide no clear trend in panel A. Muenchener Rück and Deutsche Boerse are the only firms with a premium in all years displayed and for both multiples. For Allianz I find a premium based on sales multiples in most cases but a discount for assets. If I consider German and European peer groups in panel B, I detect that there is a premium for Allianz, Commerzbank, Deutsche Boerse, HVB and Muenchener Rück. Deutsche Bank shows a premium based on sales multiples and a discount based on assets multiples. Firms in the pharmaceutical and chemical industry like Altana, BASF, Fresenius, Henkel and Schering show a premium for all excess value calculations. If I use European peer groups in panel B, the firms BASF, Bayer and Henkel have negative excess values. The automobile industry provides negative excess values for almost all methods. Only BMW has a premium based on assets multiples and German peer groups. One reason could be the high number of segments that each of the firms contain. The average number of different segments for the four firms in the automobile industry is 5 , while for the previous industry the average number of segments is 3. In the European environment German firms in the automobile industry also have a discount. The two firms in the utility industry E.ON and RWE also trade at a discount in most cases independently of the underlying peer group and the valuation method. These results can be related to the high number of segments. Telecommunication and technology

\footnotetext{
${ }^{6}$ See for instance Lang and Stulz (1994), Graham, Lemmon and Wolf (2002).
} 
Table 4: Conglomerate discount for DAX30 firms

Excess value is calculated for three representative years for all DAX 30 firms. The firms are drawn from the index put together in 2004. Excess value is the natural logarithm of the ratio between observed firm value and imputed value. The imputed value is the sum of the imputed values of each segment. A segment's imputed value is the sales or assets value of the segment multiplied with either the median ratio of the firm value to the accounting item of an industry peer group or the geometric mean of that ratio. A peer group contains only single-segment firms based on 2-digit SIC-codes. Panel A shows the results for peer groups containing only German firms, panel B the results for peer groups containing German and European firms. If the sum of segment assets deviates from total assets then segment assets are scaled to total assets with the observed proportion. If segment information are not available then excess value is not displayed.

\begin{tabular}{|c|c|c|c|c|c|c|c|c|}
\hline \multicolumn{9}{|c|}{ Panel A: German peer groups } \\
\hline \multirow[t]{3}{*}{ firm } & \multicolumn{4}{|c|}{ sales basis } & \multicolumn{4}{|c|}{ asset basis } \\
\hline & \multicolumn{2}{|c|}{ geo. mean } & \multicolumn{2}{|c|}{ median } & \multicolumn{2}{|c|}{ geo. mean } & \multicolumn{2}{|c|}{ median } \\
\hline & 1996 & 2002 & 1996 & 2002 & 1996 & 2002 & 1996 & 2002 \\
\hline Adidas & 0.97 & 0.30 & 0.92 & 0.39 & & & & \\
\hline Allianz & 0.41 & 0.14 & 0.57 & -0.04 & & -0.09 & & -0.32 \\
\hline Altana & 1.29 & 1.28 & 1.45 & 1.42 & & 1.24 & & 1.38 \\
\hline BASF & 0.37 & 0.19 & 0.54 & 0.33 & 0.47 & 0.17 & 0.45 & 0.31 \\
\hline Bayer & 0.62 & 0.36 & 0.75 & 0.47 & 0.25 & -0.06 & 0.22 & 0.04 \\
\hline BMW & -0.30 & -0.19 & -0.66 & -0.37 & 0.19 & 0.23 & 0.16 & 0.17 \\
\hline Commerzbank & -0.03 & 1.94 & -0.11 & 1.73 & & & & \\
\hline Continental & -0.21 & -0.44 & -0.36 & -0.39 & & -0.20 & & -0.19 \\
\hline DaimlerChr. & & -0.28 & & -0.39 & & -0.02 & & -0.07 \\
\hline Deutsche Bank & -0.23 & 0.24 & -0.31 & 0.00 & & -0.52 & & -0.82 \\
\hline Dt. Boerse & & 1.20 & & 1.29 & & 0.72 & & 0.58 \\
\hline Dt. Lufthansa & -1.11 & -1.01 & -0.96 & -0.80 & & -0.42 & & -0.53 \\
\hline Deutsche Post & & -0.32 & & -0.42 & & -0.09 & & -0.38 \\
\hline Dt. Telekom & 0.68 & 0.90 & 0.75 & 0.97 & & 0.68 & & 0.46 \\
\hline EON & -0.24 & -0.38 & 0.03 & 0.14 & -0.32 & -0.68 & -0.26 & -0.43 \\
\hline Fresenius & 2.38 & 0.05 & 2.27 & 0.09 & 0.91 & & 0.84 & \\
\hline Henkel & 0.11 & 0.46 & 0.25 & 0.60 & & 0.40 & & 0.53 \\
\hline HVB & 0.02 & 1.59 & -0.06 & 1.33 & & & & \\
\hline Infineon & & 0.72 & & 0.59 & & & & \\
\hline Linde & 0.82 & 0.41 & 0.86 & 0.55 & & -0.13 & & -0.01 \\
\hline MAN & -0.33 & -0.85 & -0.17 & -0.85 & & -0.38 & & -0.41 \\
\hline Metro & -1.10 & -0.52 & -0.62 & -0.81 & & -0.16 & & -0.30 \\
\hline Muenchener Rk & 0.33 & 0.31 & 0.48 & 0.58 & & 0.00 & & 0.15 \\
\hline RWE & -0.30 & -0.50 & -0.15 & 0.11 & -0.42 & -0.70 & -0.37 & -0.45 \\
\hline SAP & 1.10 & 1.70 & 0.55 & 1.78 & & & & \\
\hline Schering & 1.15 & 1.05 & 1.32 & 1.07 & & 0.70 & & 0.75 \\
\hline Siemens & -0.18 & -0.99 & -0.15 & -0.86 & -0.31 & -0.73 & -0.32 & -0.64 \\
\hline ThyssenKrupp & & -0.77 & & -0.79 & & -0.22 & & -0.21 \\
\hline TÜI & -0.35 & -0.85 & -0.06 & -0.70 & & 0.19 & & 0.11 \\
\hline Volkswagen & 0.39 & 0.17 & 0.58 & 0.22 & & -0.08 & & -0.12 \\
\hline mean & 0.25 & 0.20 & 0.31 & 0.24 & 0.11 & -0.01 & 0.10 & -0.02 \\
\hline
\end{tabular}


Panel B: European peer groups

\begin{tabular}{|c|c|c|c|c|c|c|c|c|}
\hline \multirow[t]{3}{*}{ firm } & \multicolumn{4}{|c|}{ sales basis } & \multicolumn{4}{|c|}{ asset basis } \\
\hline & \multicolumn{2}{|c|}{ geo. mean } & \multicolumn{2}{|c|}{ median } & \multicolumn{2}{|c|}{ geo. mean } & \multicolumn{2}{|c|}{ median } \\
\hline & 1996 & 2002 & 1996 & 2002 & 1996 & 2002 & 1996 & 2002 \\
\hline Adidas & 0.57 & 0.17 & 0.55 & 0.32 & & & & \\
\hline Allianz & 0.37 & 0.45 & 0.42 & 0.39 & & 0.32 & & 0.36 \\
\hline Altana & 0.15 & 0.03 & 0.58 & 0.21 & & 0.80 & & 0.93 \\
\hline BASF & -0.70 & -1.00 & -0.30 & -0.82 & -0.02 & -0.39 & 0.06 & -0.31 \\
\hline Bayer & -0.57 & -0.64 & -0.17 & -0.48 & -0.38 & -0.52 & -0.31 & -0.45 \\
\hline BMW & -0.63 & -0.10 & -0.74 & -0.04 & -0.10 & 0.26 & -0.04 & -0.01 \\
\hline Commerzbank & 0.77 & 2.20 & 0.61 & 2.15 & & & & \\
\hline Continental & -0.89 & -0.54 & -0.95 & -0.47 & & -0.38 & & -0.41 \\
\hline DaimlerChr. & & -0.45 & & -0.20 & & -0.17 & & -0.33 \\
\hline Deutsche Bank & 0.55 & 0.63 & 0.40 & 0.52 & & -0.25 & & -0.31 \\
\hline Dt. Boerse & & 0.66 & & 0.88 & & 0.43 & & 0.44 \\
\hline Dt. Lufthansa & -0.79 & -0.99 & -0.78 & -0.94 & & -0.60 & & -0.63 \\
\hline Deutsche Post & & 0.12 & & 0.19 & & 0.17 & & 0.13 \\
\hline Dt. Telekom & -0.32 & 0.75 & -0.34 & 0.53 & & 0.22 & & 0.07 \\
\hline $\mathrm{EON}$ & -0.59 & -0.45 & -0.38 & -0.43 & -0.45 & -0.69 & -0.40 & -0.57 \\
\hline Fresenius & 0.90 & -1.07 & 1.17 & -0.62 & -0.12 & & -0.10 & \\
\hline Henkel & -0.92 & -0.80 & -0.56 & -0.63 & & -0.05 & & 0.07 \\
\hline HVB & 0.82 & 2.11 & 0.66 & 1.93 & & & & \\
\hline Infineon & & 0.22 & & 0.42 & & & & \\
\hline Linde & -0.03 & -0.48 & 0.15 & -0.31 & & -0.51 & & -0.41 \\
\hline MAN & -0.81 & -1.34 & -0.74 & -1.03 & & -0.90 & & -0.84 \\
\hline Metro & -1.00 & -0.57 & -1.03 & -0.66 & & -0.21 & & -0.27 \\
\hline Muenchener Rk & 0.28 & 0.06 & 0.33 & 0.22 & & 0.41 & & 0.92 \\
\hline RWE & -0.82 & -0.62 & -0.68 & -0.62 & -0.75 & -0.63 & -0.74 & -0.51 \\
\hline SAP & 1.28 & 1.17 & 1.48 & 1.29 & & & & \\
\hline Schering & 0.02 & -0.03 & 0.45 & 0.11 & & 0.35 & & 0.44 \\
\hline Siemens & -1.01 & -1.28 & -0.80 & -1.26 & -0.89 & -0.46 & -0.83 & -0.40 \\
\hline ThyssenKrupp & & -1.04 & & -0.81 & & -0.67 & & -0.65 \\
\hline TUI & -0.84 & -1.10 & -0.68 & -0.83 & & -0.42 & & -0.41 \\
\hline Volkswagen & -0.30 & -0.54 & -0.13 & -0.11 & & -0.72 & & -0.54 \\
\hline mean & -0.18 & -0.15 & -0.06 & -0.04 & -0.39 & -0.19 & -0.34 & -0.15 \\
\hline
\end{tabular}


firms from Deutsche Telekom to SAP show a strong premium based on German and European peer groups, respectively. Deutsche Lufthansa and Deutsche Post show a discount for German peer firms. If I use European peer firms Deutsche Lufthansa still has a discount while Deutsche Post a premium. Metro is the only firm that operates in the retail and wholesale industry. This firm consists of 7 segments on average and trades at a discount for all specifications and all peer groups. The next four firms Linde, MAN, Siemens and Thyssen Krupp are manufacturing firms. The average number of segments for this industry group is relatively high with 7 segments. For MAN, Siemens and Thyssen Krupp I detect discounts with a broad range, while Linde shows a premium for most specifications. The last two firms operate in the consumer industry. Adidas Salomon has 3 segments on average and shows a premium between 0.17 and 0.97 , while TUI has a discount between 0.11 and -1.10. The results of this analysis show that discounts and premiums depend on three determinants. First, firms with a high number of segments like Siemens (10 segments), ThyssenKrupp (9 segments), RWE (8 segments) or MAN (7 segments) tend to have a high excess value. Second, for several industries like banking and financial service providers, automobile producers or utilities I find a discount for all member firms. One reason is the higher diversification of some industries another seems to be a general undervaluation. Third, the underlying peer groups have a significant influence on the valuation results.

Overall, I find that pure German and mixed German and European peer groups lead to different results. I also document that the discount for German firms is low on average but the fluctuation from one year to the next is high. I will now discuss some explanations for these findings.

\section{Explaining the Conglomerate Discount}

In this section I will provide several explanations for my previous results that there exists a conglomerate discount in Germany. The first analysis shows how uncertainties about valuation have developed over time and how this is related to the conglomerate discount. I measure the variation of multiples and assume that a higher variation 
leads to higher valuation errors and higher excess values. In my second analysis I calculate different diversification measures and their change over time. I relate these results to the development of the conglomerate discount over time. My assumption is that a higher degree of diversification over all firms within one year leads to a higher discount, while a lower diversification leads to a lower discount. I support the analysis by running fixed-effects regressions.

\subsection{Uncertainties about Valuation}

In this section I want to find out whether there is a relation between uncertainties about valuation and the conglomerate discount. I expect to find that a significant fraction of the diversification discount is caused by valuation errors and variation of multiples and not by a general undervaluation of conglomerates. Due to the fact that the selection of peer groups is of critical importance for the valuation accuracy, one should see a better prediction of the real firm value, if the variance between the peer multiples is relatively low. On the other hand if the variance is high, one should see higher valuation errors that can deviate in both directions. Bhojraj and Lee (2003) show that a classification of firms that have more homogeneous financial ratios provide more accurate valuation predictions. Dittmann and Maug (2005) show that an increase in the standard deviation within industries by $1 / 3$ leads to an increase in valuation errors of more than $100 \%$ for percentage errors.

I calculate the annual variation in multiples $\mathrm{V}$, i.e. the overall average standard deviation of multiples within industries of segments, by

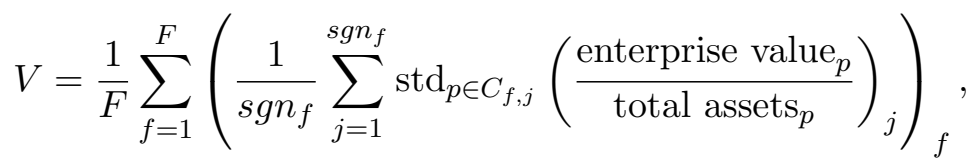

where $\operatorname{std}_{p \in C_{f, j}}\left(\frac{\text { enterprise value }_{p}}{{\text { total } \operatorname{assets}_{p}}_{j}}\right)_{j}$ is the standard deviation of the peer group multiples of segment $j$, sgn contains the number of different segments of firm $f$ and $F$ is the number of all firms in the sample. $C_{f, j}$ is the peer group for firm f's segment $\mathrm{j}$. The sample covers all multi-segment firms from the previous investigation (Table 1, Panel A). 
Figure 1 shows the relationship between conglomerate discount and variation of multiples from 1991 to 2003. The black line and the right y-axis display the average excess value over all firms in one year, where excess value is defined as the natural logarithm of the ratio between observed firm value and imputed value. The imputed value is the sum of the imputed values of each segment. A segment's imputed value is the sales value of the segment multiplied with the geometric mean ratio of the firm value to sales of an industry peer group. The grey line and the left y-axis present the average variation of multiples.

Figure 1: Uncertainties of valuation

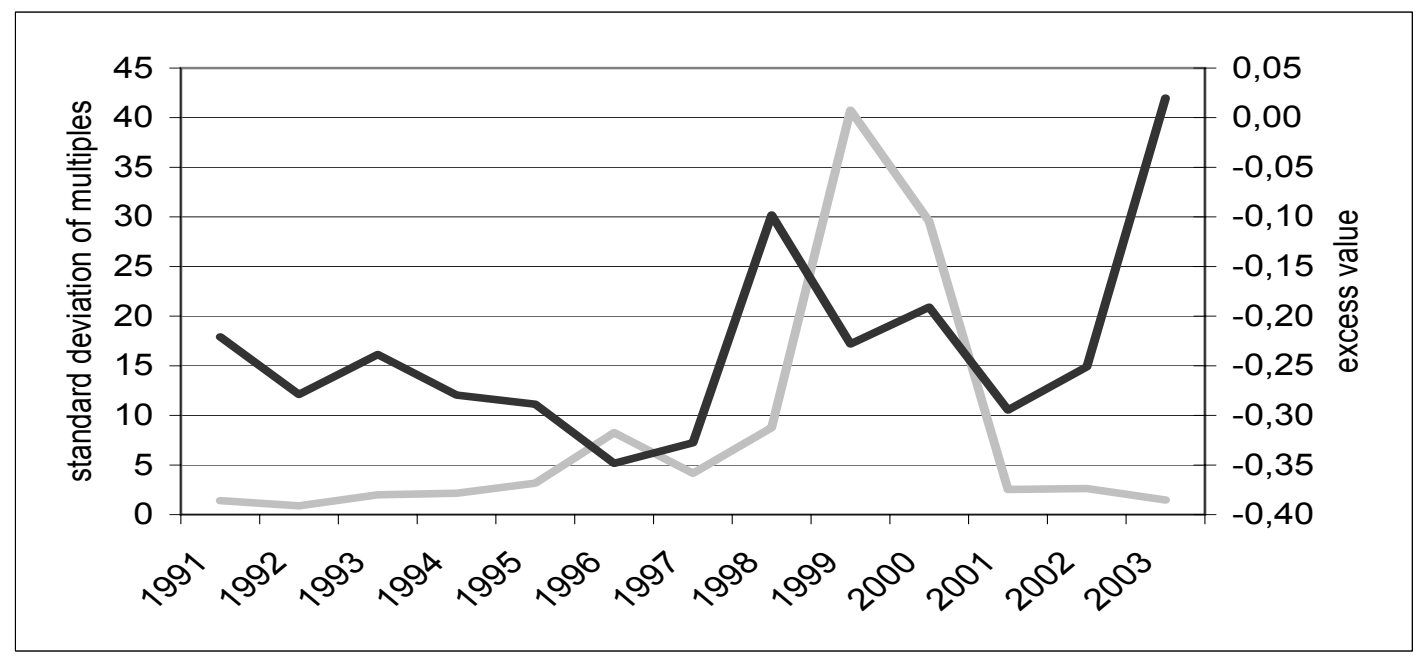

The graphs give an indication how valuation uncertainty is related to the conglomerate discount and how it changes over time. Between 1991 and 1996 the average excess value changes from about -0.22 to -0.35 and the standard deviation of multiples within peer groups also changes from about 1 to 8 . This is coherent with the idea that a higher uncertainty of valuation leads to a higher deviation between the estimated and the observed value. In 1997 and 1998 excess values change from -0.35 to -0.10 , while valuation uncertainty increase from about 5 to 40 . From 1999 to 2000 there is no clear trend that could explain the relationship between excess value and valuation uncertainty. Between 2001 and 2003 the standard deviation of multiples increase sharply from 10 to over 40 . On the other hand the conglomerate discount 
is on a very low level.

I would expect that a higher uncertainty of valuation, i.e. a higher coefficient of variation is related to a lower valuation reliability of the company. In the context of the conglomerate discount problem one might see a discount or a premium that is not caused by fundamental characteristics of conglomerate structures but by valuation accuracy; i.e. the possibility of an over- or underestimation of the conglomerate discount increases.

To present a more detailed investigation between excess value and valuation uncertainty I use a regression analysis between the excess value and the variation of multiples. I calculate uncertainty about valuation for each company according to equation 2. I use 2 different specifications for the regression. The first specification is defined by the equation

$$
(\text { Excess Value })=\alpha+\beta(\text { Variation of Multiples })+\epsilon,
$$

where (Variation of Multiples) is the average standard deviation of multiples over all segments of a firm and excess value is the natural logarithm of the ratio between observed firm value and imputed value. The imputed value is the sum of the imputed values of each segment. A segment's imputed value is the sales value of the segment multiplied with the geometric mean ratio of the firm value to sales of an industry peer group. With the first specification I want to test the effect of valuation accuracy on possible discounts. It is an obvious result that this is only an indication of the influence of valuation effects because these effects deviate in both directions. The second specification takes both directions of deviation into account and covers the possibility of an over- or- undervaluation. It is defined as

$$
\mid(\text { Excess Value }) \mid=\alpha+\beta \text { (Variation of Multiples })+\epsilon,
$$

where I use the absolute excess value as the dependent variable. Table 5 presents the results of my analysis separately for each year from 1991 to 2003. Displayed are the number of observations, the coefficients for each specification and the significance levels. 
Table 5: Excess value and uncertainty about valuation

This table displays the relationship between excess value and the variation of multiples separately for each year from 1991 to 2003. I cover all multi-segment firms. Excess values is the dependent variable. It is the natural logarithm of the ratio between the observed firm value and the imputed value. The imputed value is the sum of the imputed values of each segment. A segment's imputed value is the sales value of the segment multiplied with the geometric mean ratio of the firm value to sales of an industry peer group. The variation of multiples for one firm is the average variation of multiples over all segments. The variation for one segment is measured as the standard deviation of peer group multiples. Specification 1 shows the coefficients of the described regression, specification 2 defines excess value as an absolute value.

\begin{tabular}{llll}
\hline year & \#firms & Specification 1 & Specification 2 \\
\hline 1991 & 177 & 0.00203 & $0.05664 * * *$ \\
1992 & 180 & 0.00203 & $0.12134 * * *$ \\
1993 & 207 & -0.02591 & $0.07281 * * *$ \\
1994 & 213 & $-0.03751 * * *$ & $0.03928 * * *$ \\
1995 & 224 & -0.01811 & $0.02639 * * *$ \\
1996 & 241 & $-0.01523 * *$ & $0.02076 * * *$ \\
1997 & 248 & -0.00023 & $0.01103 * * *$ \\
1998 & 260 & -0.00032 & $0.00116 *$ \\
1999 & 301 & 0.00046 & $0.00131 * *$ \\
2000 & 333 & $-0.00171 *$ & 0.00037 \\
2001 & 387 & -0.02731 & $0.05126 * * *$ \\
2002 & 399 & $-0.03102 * *$ & 0.00685 \\
2003 & 400 & $0.17145 * *$ & $0.11129 *$ \\
\hline
\end{tabular}

$* * *, * *, *$ indicates significance at $1 \%, 5 \%, 10 \%$ level

The results indicate that there is a relationship between the variation of multiples and the conglomerate discount. The coefficients of the first regression show that there is a negative relation between the dependent and independent variable. This means that a high variation of multiples leads to a high diversification discount. Only in 1991, 1992, 1999 and 2003 the coefficients are positive. Significance indicates that there is weak relationship between valuation uncertainty and excess value. In 5 years the regression is significant, while in the remaining 8 years I observe no significance. The coefficients of the second specification show the relationship between valuation uncertainty and excess value, independently, whether it is a discount or a premium. Interestingly, all years except 2000 and 2002 show a significant relationship. I would 
assume this relationship, because a higher dispersion of multiples leads to lower valuation accuracy and this results in a higher deviation between the observed enterprise value and the estimated enterprise value. The result is a higher possibility of an overor undervaluation.

I conclude, based on the observation of the previous results, that the selection of peer groups and the definition and determination of industries is of critical importance to get reliable insights. A higher variation within industries can lead to an overor undervaluation, which means that the conglomerate discount or conglomerate premium might in some cases not only be caused by the conglomerate structure itself but also by the valuation procedure.

\subsection{Conglomerate Discount and Diversification}

In this section I test how diversification changes over time and how it is related to the conglomerate discount. One can assume that a low average diversification within one year is related to a moderate excess value. On the other hand if I find a high diversification, which is defined by a higher number of segments per firm and a higher dispersion of sales over segments, then I would expect a higher diversification discount. I use three measures of diversification. For each firm $\mathrm{f}$ I calculate the Herfindahl index $\mathrm{H}$ which is defined as

$$
H_{f}=\sum_{j=1}^{s g n_{f}}\left(\frac{\operatorname{sales}_{j, f}}{\operatorname{sales}_{f}}\right)^{2},
$$

where sgn is the number of segments for firm $\mathrm{f}$, sales $_{j, f}$ is net sales for the segment $\mathrm{j}$ of firm $\mathrm{f}$ and sales $_{f}$ are total sales for firm $\mathrm{f}$. If $\mathrm{H}$ is equal to one then the underlying firm has only one segment. If $\mathrm{H}$ is close to zero, then the underlying firms has many segments and each segment has a similar distribution of sales values. The second and third measure of diversification are the concentration ratios $\mathrm{C} 4$ and $\mathrm{C} 8$ for firm $\mathrm{f}$ that are defined as

$$
C 4_{f}=\frac{\sum_{j=1}^{4} \text { sales }_{j}}{\text { sales }_{f}}
$$


Table 6: Descriptive statistics of diversification

This table displays descriptive statistics of three diversification measures. Herf refers to the Herfindahl index based on segment sales, $\mathrm{C} 4$ and $\mathrm{C} 8$ are the concentration ratios for the first four and eight segments, respectively. The last column shows excess value. All values are averaged over firms.

\begin{tabular}{lllllr}
\hline year & \#firms & Herf & C4 & C8 & EXV \\
\hline 1991 & 177 & 0.628 & 0.972 & 1.000 & -0.221 \\
1992 & 180 & 0.613 & 0.936 & 0.991 & -0.269 \\
1993 & 207 & 0.634 & 0.938 & 0.995 & -0.239 \\
1994 & 213 & 0.632 & 0.938 & 0.990 & -0.279 \\
1995 & 224 & 0.640 & 0.938 & 1.000 & -0.289 \\
1996 & 241 & 0.644 & 0.941 & 0.997 & -0.348 \\
1997 & 248 & 0.650 & 0.957 & 0.992 & -0.328 \\
1998 & 260 & 0.657 & 0.957 & 0.986 & -0.098 \\
1999 & 301 & 0.703 & 0.980 & 1.000 & -0.228 \\
2000 & 333 & 0.686 & 0.970 & 1.000 & -0.191 \\
2001 & 387 & 0.717 & 0.962 & 0.997 & -0.295 \\
2002 & 399 & 0.773 & 0.964 & 0.997 & -0.251 \\
2003 & 400 & 0.766 & 0.966 & 0.994 & 0.020 \\
\hline
\end{tabular}

$$
C 8_{f}=\frac{\sum_{j=1}^{8} \text { sales }_{j}}{\text { sales }_{f}},
$$

where the $\mathrm{C} 4$ concentration ratio measures the share of the four largest segment sales and the $\mathrm{C} 8$ concentration measures the share of the 8 largest segment sales. Table 6 provides descriptive statistics of diversification measures from 1991 to 2003. I also display excess values in the last column.

Between 1991 and 2003 I detect an increase of the Herfindahl index from 0.628 to 0.766 . The C4 measure is similar in 1991 and 2003 but there is an increase between 1992 to 2003 from 0.936 to 0.964 . The C8 measure is in all years close to 1.000. The increase of the Herfindahl index and the C4 measure from 1992 to 
1999 is coherent with my previous findings that show an increase of the variation of multiples between 1992 and 1999. In 2000 diversification - measured by Herfindahl index and C4 measure - decreases, while it continues to increase from 2001 to 2003. The average conglomerate discount shows a similar pattern. From 1991 to 1997 excess values change from -0.221 to -0.328 . In 1998 I detect an extraordinary low value. From 1999 to 2002 I see significant changes from -0.228 to -0.295 and in 2003 there is a conglomerate premium of 0.020. Between 1991 and 1997 one can explain the conglomerate discount with an increase of diversification. Between 1998 and 2003 the results provide not such a clear trend.

I will now conduct a regression analysis between diversification and the conglomerate discount to get more detailed and reliable results between these two measures. Table 7 shows the coefficients where the dependent variable is excess value defined as in the regressions before and three diversification definitions as the independent variable. I perform one regression for each diversification measure and use OLS as well as year-fixed effects specifications. This allows me to control for unobservable time effects.

The results show that all coefficients are positive and significant. The differences between OLS and fixed effect regression are low, but I see that OLS coefficients are always higher. The analysis provides evidence that a lower average degree of diversification is correlated with a lower conglomerate discount.

\section{Diversification and Corporate Governance}

In this section I relate the diversification discount to corporate governance behavior. I use the DAX 30 firms for this analysis. I assume that a significant fraction of the value difference between conglomerates and single-segment firms is caused not only by higher agency costs due to structural determinants but by corporate governance and firm policy.

Classical arguments to explain the conglomerate discount are that additional agency costs arise from ineffective internal capital markets, suboptimal incentive compensation for managers, information asymmetries between segment managers as 
Table 7: Excess value and diversification

This table displays the relationship between excess value and the diversification measures Herfindahl index, $\mathrm{C} 4$ and $\mathrm{C} 8$. It provides coefficients and regression statistics. Specification 1 shows the coefficients of an OLS regression. Specification 2 shows the coefficients of a year-fixed effects regression. Values in parentheses show estimation errors.

\begin{tabular}{llll}
\hline variable & \#firms & Specification 1 & Specification 2 \\
\hline HERF & 3398 & $0.13794 * *$ & $0.12562 * *$ \\
& & $(0.05904)$ & $(0.05966)$ \\
adj $R^{2}$ & & 0.0013 & 0.0071 \\
F Value & & 5.46 & 2.88 \\
\hline C4 & 3398 & $0.16679 * *$ & $0.15654 * *$ \\
& & $(0.05312)$ & $(0.05354)$ \\
adj $R^{2}$ & & 0.0068 & 0.0084 \\
F Value & & 5.21 & 3.02 \\
\hline C8 & 3398 & $0.17471 * * *$ & $0.16337 * *$ \\
& & $(0.05022)$ & $(0.05012)$ \\
adj $R^{2}$ & & 0.0077 & 0.0052 \\
F Value & & 6.43 & 3.22 \\
\hline
\end{tabular}

$* * *, * *, *$ indicates significance at $1 \%, 5 \%, 10 \%$ level

well as increased incentives for rent seeking by managers. Corporate governance makes it possible to overcome these deficits of conglomerates by providing information, control and legal protection. Shleifer and Vishny (1997) give a comprehensive overview about agency problems and the influence of corporate governance, which supports my idea.

There is a large number of papers that deal with corporate governance and related topics. Drobetz, Schillhofer and Zimmermann (2003) construct a corporate governance index for German firms and investigate the relationship between corporate governance and firm value. They show that firms with higher corporate governance ratings exhibit higher firm values. Their results are statistically significant. Bauer, Gunster and Otten (2004) examine how corporate governance affects the firm value. 
They use two datasets based on U.K. and European Monetary Union (EMU) firms and show that a good corporate governance behavior leads to higher firm values. A good corporate governance behavior in this context is measured by the degree of "Rights and Duties of Shareholders", "Range of Takeover Defenses", "Disclosure on Corporate Governance" and "Board Structure and Functioning". Fauver, Houston and Naranjo (2002) investigate the relationship between the capital market development of 35 countries and the conglomerate discount of more than 8,000 firms. They find that the discount of diversified firms is less extensive in countries, where capital markets and economic and legal systems are less developed, while it is higher in countries with well established capital markets and better structural conditions. They argue that diversified firms obtain benefits from internal capital markets especially in countries with costly and less developed external capital markets. Gompers, Ishii, and Metrick (2003) construct a corporate governance index for 1,500 firms and provide evidence that there is a positive relationship between corporate governance behavior and firm value. Black (2001) supports their finding. He has a sample of 21 Russian firms and shows a statistically significant relationship between corporate governance and firm value. Black, Jang, Kim (2005) show similar results for Korean firms. Beier and Schmid (2005) examine the relationship between corporate governance and conglomerate discount for a sample of Swiss firms. They find a discount between $14 \%$ and $24 \%$ but they are not able to provide evidence for a relation between value loss from diversification and corporate governance behavior. They only show that single-segment firms have a better corporate governance compared to multi-segment firms.

I use an index provided by the Institutional Shareholder Service, which is freely available $^{7}$ for the DAX 30 firms. It comprises 55 corporate governance criteria within eight different categories: (1) Audit/Auditor Independence, (2) Board Structure and Composition, (3) Charter and Bylaw Provisions, (4) Anti-takeover Provisions, (5) Executive and Director Pay, (6) Directors and Officers Ownership, (7) Progressive Practices and (8) Director Education. Appendix A shows the complete list of the 55

\footnotetext{
${ }^{7}$ source: HANDELSBLATT, Tuesday, January 12, 2005
} 
governance variables. Corporate governance values for each company are based on these 55 variables with different weights. The weighting calculations are determined by the correlation of each variable with various performance measures ${ }^{8}$. Thus, the higher the variable correlation significance with specific performance measures is, the higher the weight of this variable in the rating is. The lower the correlation significance between the variable and the performance metrics is, the lower the weight assigned to the variable is ${ }^{9}$. The corporate governance measure for one company is provided relative to an underlying index or an industry peer group on a percentile basis. For instance, a company with a corporate governance index rating of 85 and a corporate governance industry rating of 91 outscores $85 \%$ of its market peers and $91 \%$ of its industry competitors. For companies in the United States the underlying market indices are the S\&P 500, the S\&P (mid-cap) 400, S\&P (small-cap) 600 and the Russell 3000. For all companies (U.S. and non-U.S.) industry peers are based on 23 industry groups selected from the Global Industry Classification Standard (GICS) developed by Morgan Stanley Capital International (MSCI) and Standard \& Poor's $(\mathrm{S} \& \mathrm{P})$. The lowest possible corporate governance value is 0 the highest 100 . For the DAX 30 firms values are measures relative to a GICS industry peer group for each firm and to the MSCI EAFE index, which covers 1070 international firms. I call the first method "industry" and the second "international".

Table 8 shows the descriptive statistics of the corporate governance value for a firm from the DAX 30 relative to a peer group of 1,070 international firms and relative to firms from the same industry based on the GICS classification system. A corporate governance value of 100 indicates that the firm has the best corporate governance behavior relative to its peer group, while a value of 0 indicates the worst behavior.

The firm with the best corporate governance behavior in the DAX 30 is SAP, which has a relative value of 84.6 in the international environment. DaimlerChrysler is the best firm relative to its industry peer firms. The mean number of 55.0 shows

\footnotetext{
${ }^{8}$ Performance measures are profitability (ROIC, ROE, ROI, EBITDA margin, etc.); valuation (Price to Book, Cash Flow, and Earnings); market (Tobin's Q); and, risk (Volatility and Z Score).

${ }^{9}$ I have no specific information about the true weights of each variable.
} 
Table 8: Descriptive statistics of corporate governance index

This table displays the descriptive statistics of the corporate governance index for the DAX 30 firms. The first row shows corporate governance behavior relative to a sample of 1,070 international firms from the MSCI EAFE index, the second row to comparable firms from the same industry. Index values range between 0 and 100, where 0 indicates a low corporate governance behavior and 100 a high behavior.

\begin{tabular}{lccccc}
\hline Index type & min & mean & median & max & std \\
\hline international index & 13.7 & 55.0 & 61.3 & 84.6 & 23.5 \\
industry index & 12.5 & 53.6 & 57.9 & 90.9 & 24.2 \\
\hline
\end{tabular}

that almost one half of the 1,070 reference firms have a better corporate governance behavior than the average DAX 30 firms. $53.6 \%$ of the firms are worse than the Dax 30 firms on average. This indicates that German firms have only an average corporate governance performance.

I construct a simple regression with two specifications to show the relationship between corporate governance and conglomerate value. The first specification uses excess value based on median peer group averaging, while the second specification uses geometric mean. For each specification I perform two separate regressions. The first contains the corporate governance index relative to international firms, the second is relative to industry peer firms. I also control for size measured by the natural logarithm of total assets. Table 9 displays the coefficients and standard errors.

The results show that all coefficients are positive and significant. This means that firms with a well established corporate governance behavior tend to be traded at a lower discount or even a premium, while firms with a low corporate governance rating are traded at a significant discount ${ }^{10}$. The differences between specification 1 and 2 are marginal. The coefficients for the industry index are higher than for the international index. The overall results provide evidence that a good corporate gover-

\footnotetext{
${ }^{10} 26$ firms in the DAX 30 are conglomerates. Therefore, all of these should have a conglomerate discount.
} 
Table 9: Regression estimation of excess value to corporate governance

This table displays the results of the ordinary-least-square regression between excess value and corporate governance. Specification 1 uses excess value based on median peer group averaging as the dependent variable, specification 2 uses geometric mean. I perform two regressions for each specification. One uses the corporate governance index relative to international firms, the other uses the index relative to industry peer firms. I use the natural logarithm of total assets to control for size. Standard errors are shown in parentheses.

\begin{tabular}{lll}
\hline Independent variables & Specification 1 & Specification 2 \\
\hline international index & $0.02067^{*}$ & $0.02175^{*}$ \\
& $(0.01150)$ & $(0.01253)$ \\
$\log$ (total assets) & -0.10647 & -0.09264 \\
& $(0.16387)$ & $(0.17453)$ \\
adj $R^{2}$ & 0.0635 & 0.0546 \\
F Value & 1.98 & 1.84 \\
\hline industry index & $0.02751^{* *}$ & $0.03017^{* *}$ \\
& $(0.01119)$ & $(0.01178)$ \\
$\log ($ total assets) & -0.12282 & -0.24892 \\
& $(0.37021)$ & $(0.38974)$ \\
adj $R^{2}$ & 0.1240 & 0.1360 \\
F Value & 3.05 & 3.28 \\
\hline
\end{tabular}

$* * *, * *, *$ indicates significance at $1 \%, 5 \%, 10 \%$ level

nance is one component that lowers the valuation discount caused by a conglomerate structure.

\section{Conclusion}

This paper investigates valuation effects of diversification in Germany. While some papers document only a modest or no discount, I find a significant discount for several years. The reason is that the other papers cover years with low discounts or calculate average excess values over several years, which leads to low discounts. There is no reason why one should assume that there is in general no discount in Germany. I document that excess values range between -0.25 in 1991 and 0.29 in 2003, while the average value is -0.10 based on unbiased measures. If I use peer groups that 
contain German and European firms together, I find much higher discounts. This is not caused by a generic undervaluation of German firms. One reason could be that the higher number of peer firms leads to more stable results.

I am also able to show that the valuation discount of conglomerates is related to the extend of diversification. Additionally, I examine the relationship between the diversification discount and corporate governance and present results that indicate a positive influence of corporate governance on excess values. The argument behind this is that corporate governance overcomes the problem of additional agency costs associated with conglomerates.

\section{References}

- Alford, Andrew W. (1992): The effect of the set of comparable firms on the accuracy of the price-earnings valuation method, Journal of Accounting Research, 30, pp. $94-108$.

- Bauer, Rob, Nadja Gunster, and Roger Otten (2004): Empirical evidence on corporate governance in Europe, Journal of Asset Management, 5, pp. 91-104.

- Berger, Philip G., and Eli Ofek (1995) Diversification's effect on firm value, Journal of Financial Economics, 37, pp. 39-65.

- Bhojraj, Sanjeev, Charles M. C. Lee, and Derek K. Oler (2003) What's my line? A comparison of industry classification schemes for capital market research, Journal of Accounting Research, 41, pp. 745-774.

- Beiner, Stefan, and Markus M. Schmid (2005) Agency conflicts, corporate governance, and corporate diversification - evidence from Switzerland, working paper, University of Basel.

- Black, Bernard (2001): The corporate governance behavior and market value of Russian firms, Emerging Markets Review, 2, pp. 89-108.

- Black, Bernard S., Hasung Jang, and Woochan Kim (2005): Does corporate governance predict firms' market values? Evidence from Korea, Journal of Law, Economics and Organization, forthcoming. 
- Brown, Lawrence D., and Marcus L. Caylor (2004): Corporate governance and firm performance, working paper, Georgia State University.

- Campa, Jose Manuel, and Simi Kedia (2002): Explaining the diversification discount, Journal of Finance, 57, pp. 1731-1762.

- Dittmann, Ingolf, and Christian Weiner (2004): Selecting comparables for the valuation of European firms, working paper, Humboldt-Universität zu Berlin.

- Dittmann, Ingolf, and Ernst Maug (2005): Biases and errors of valuation procedures: with an application to the conglomerate discount, working Paper, Humboldt-Universität zu Berlin.

- Doukas, John A., and Ozgur B. Kan (2004): Excess cash flows and diversification discount, Financial Management, 22, pp. 5-22.

- Drobetz, Wolfgang, Andreas Schillhofer, and Heinz Zimmermann (2003): Corporate governance and expected stock returns: evidence from Germany, ECGI Working Paper Series 011/2003.

- Fan, Joseph P. H., and Larry H. P. Lang (2002): The measurement of relatedness: an application to corporate diversification, Journal of Business, 73, pp. 629-660.

- Fauver, Larry, Joel Houston, and Andy Naranjo (2002): Capital market development, integration, legal systems, and the value of corporate diversification: a cross-country analysis, Journal of Financial and Quantitative Analysis, 38, pp. $135-157$.

- Graham, John R.; Michael Lemmon, and Jack Wolf (2002): Does corporate diversification destroy value?, Journal of Finance, 57, pp. 695-720.

- Gompers, Paul A., Joy L. Ishii, and Andrew Metrick (2003) Corporate governance and equity prices, Quarterly Journal of Economics, 18, pp. 107-155.

- Gugler, Klaus, and Burcin Yurtoglu (2003): Corporate governance and dividend pay-out policy in Germany, European Economic Review, 47, pp. 731-758.

- Klapper, Leora F., and Inessa Love (2004): Corporate governance, investor protection, and performance in emerging markets, Journal of Corporate Finance, 
10, pp. $703-728$.

- Lamont, Owen A., and Christopher Polk (1999): The diversification discount: cash flow vs. returns, NBER working paper, no. 7396.

- La Porta, Rafael, Florencio Lopez-de-Silanes, and Andrei Shleifer (1999): Corporate ownership around the world, The Journal of Finance, 54, pp. 471-517.

- La Porta, Rafael, Florencio Lopez-de-Silanes, Andrei Shleifer, and Robert Vishny (2000): Investor protection and corporate governance, Journal of Financial Economics, 58, pp. 3-27.

- Lang, Larry, and Rene Stulz (1994): Tobin's Q, Corporate diversification and firm performance, Journal of Political Economy, 102, pp. 1248-1280.

- Lins, Karl, and Henry Servaes (1999): International evidence on the value of corporate diversification, Journal of Finance, 54, pp. 2215-2239.

- Lins, Karl, and Henry Servaes (2002): Is corporate diversification beneficial in emerging markets?, Financial Management, 31, pp. 5-31.

- Mansi, Sattar A., and David M. Reeb (2002): Corporate diversification: what gets discounted?, working paper, Rawls School of Business, Texas Tech University.

- Martin, John D., and Akin Sayrak (2003): Corporate diversification and shareholder value, Journal of Corporate Finance, 9, pp. 37-57.

- Reimund, Carsten, and Bernhard Schwetzler (2003): Conglomerate discount and cash distortion: New evidence from Germany, HHL working paper, No. 60.

- Schoar, Antoinette S. (2002): Effects of corporate diversification on productivity, Journal of Finance, 57, pp. 2379-2403.

- Servaes, Henri (1996): The value of diversification during the conglomerate merger wave, Journal of Finance, 51, pp. 1201-1225.

- Shleifer, Andrei, and Rovert W. Vishny (1997): A survey of corporate governance, Journal of Finance, 52, pp. 737-783. 
- Villalonga, Belen (2004a): Diversification discount or premium? new evidence from BITS establishment-level data, Journal of Finance, 59, pp. 479-506.

- Villalonga, Belen (2004b): Does diversification cause the diversification discount?, Financial Management, 33, pp. 5-27. 


\section{Appendix A: List of Corporate Governance Vari- ables}

This list displays all corporate governance variables use for the calculation of the corporate governance rating. Information are from the Institutional Shareholder Services.

1 Board Composition

$2 \quad$ Nominating Committee

3 Compensation Committee

$4 \quad$ Governance Committee

$5 \quad$ Board Structure

$6 \quad$ Board Size

$7 \quad$ Changes In Board Size

8 Cumulative Voting

$9 \quad$ Boards Served On - CEO

10 Boards Served On - Other

Than CEO

11 Former CEOs

12 Chairman/CEO Separa-

tion

13 Board Guidelines

14 Response To Shareholder

Proposals

15 Board Attendance

16 Board Vacancies

17 Related Party Transactions

Audit

18 Audit Committee

19 Audit Fees

20 Auditor Rotation

21 Auditor Ratification

Charter/Bylaws

22-27 Features of Poison Pills

28-29 Vote Requirements

30 Written Consent

$31 \quad$ Special Meetings

32 Board Amendments

$33 \quad$ Capital Structure
Anti-Takeover Provisions

34 Anti-Takeover Provisions Applicable

Under Country (local) Laws

Executive and Director Compensation

35 Cost of Option Plans

36-37 Option Re-pricing

38 Shareholder Approval of Option Plans

39 Compensation Committee Interlocks

40 Director Compensation

41 Pension Plans For Non-Employee Di-

rectors

$42 \quad$ Option Expensing

43 Option Burn Rate

$44 \quad$ Corporate Loans

Qualitative Factors

45 Retirement Age for Directors

46 Board Performance Review

$47 \quad$ Meetings of Outside Directors

48 CEO Succession Plan

49 Outside Advisors Available To Board

50 Directors Resign Upon Job Change Ownership

51 Director Ownership

52 Executive Stock Ownership Guidelines

53 Director Stock Ownership Guidelines

$54 \quad$ Officer And Director Stock Ownership

Director Education

$55 \quad$ Director Education 


\section{SFB 649 Discussion Paper Series}

For a complete list of Discussion Papers published by the SFB 649, please visit http://sfb649.wiwi.hu-berlin.de.

001 "Nonparametric Risk Management with Generalized Hyperbolic Distributions" by Ying Chen, Wolfgang Härdle and Seok-Oh Jeong, January 2005.

002 "Selecting Comparables for the Valuation of the European Firms" by Ingolf Dittmann and Christian Weiner, February 2005.

003 "Competitive Risk Sharing Contracts with One-sided Commitment" by Dirk Krueger and Harald Uhlig, February 2005.

004 "Value-at-Risk Calculations with Time Varying Copulae" by Enzo Giacomini and Wolfgang Härdle, February 2005.

005 "An Optimal Stopping Problem in a Diffusion-type Model with Delay" by Pavel V. Gapeev and Markus Reiß, February 2005.

006 "Conditional and Dynamic Convex Risk Measures" by Kai Detlefsen and Giacomo Scandolo, February 2005.

007 "Implied Trinomial Trees" by Pavel Čížek and Karel Komorád, February 2005.

008 "Stable Distributions" by Szymon Borak, Wolfgang Härdle and Rafal Weron, February 2005.

009 "Predicting Bankruptcy with Support Vector Machines" by Wolfgang Härdle, Rouslan A. Moro and Dorothea Schäfer, February 2005.

010 "Working with the XQC" by Wolfgang Härdle and Heiko Lehmann, February 2005.

011 "FFT Based Option Pricing" by Szymon Borak, Kai Detlefsen and Wolfgang Härdle, February 2005.

012 "Common Functional Implied Volatility Analysis" by Michal Benko and Wolfgang Härdle, February 2005.

013 "Nonparametric Productivity Analysis" by Wolfgang Härdle and Seok-Oh Jeong, March 2005.

014 "Are Eastern European Countries Catching Up? Time Series Evidence for Czech Republic, Hungary, and Poland" by Ralf Brüggemann and Carsten Trenkler, March 2005.

015 "Robust Estimation of Dimension Reduction Space" by Pavel Čížek and Wolfgang Härdle, March 2005.

016 "Common Functional Component Modelling" by Alois Kneip and Michal Benko, March 2005.

017 "A Two State Model for Noise-induced Resonance in Bistable Systems with Delay" by Markus Fischer and Peter Imkeller, March 2005.

018 "Yxilon - a Modular Open-source Statistical Programming Language" by Sigbert Klinke, Uwe Ziegenhagen and Yuval Guri, March 2005.

019 "Arbitrage-free Smoothing of the Implied Volatility Surface" by Matthias R. Fengler, March 2005.

020 "A Dynamic Semiparametric Factor Model for Implied Volatility String Dynamics" by Matthias R. Fengler, Wolfgang Härdle and Enno Mammen, March 2005.

021 "Dynamics of State Price Densities" by Wolfgang Härdle and Zdeněk Hlávka, March 2005.

022 "DSFM fitting of Implied Volatility Surfaces" by Szymon Borak, Matthias R. Fengler and Wolfgang Härdle, March 2005.

\section{SFB 649, Spandauer Straße 1, D-10178 Berlin http:/ / sfb649.wiwi.hu-berlin.de}

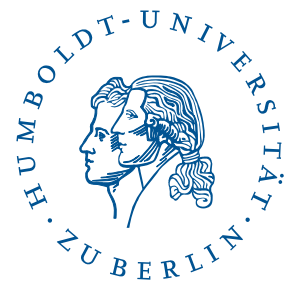


023 "Towards a Monthly Business Cycle Chronology for the Euro Area" by Emanuel Mönch and Harald Uhlig, April 2005.

024 "Modeling the FIBOR/EURIBOR Swap Term Structure: An Empirical Approach" by Oliver Blaskowitz, Helmut Herwartz and Gonzalo de Cadenas Santiago, April 2005.

025 "Duality Theory for Optimal Investments under Model Uncertainty" by Alexander Schied and Ching-Tang Wu, April 2005.

026 "Projection Pursuit For Exploratory Supervised Classification" by EunKyung Lee, Dianne Cook, Sigbert Klinke and Thomas Lumley, May 2005.

027 "Money Demand and Macroeconomic Stability Revisited" by Andreas Schabert and Christian Stoltenberg, May 2005.

028 "A Market Basket Analysis Conducted with a Multivariate Logit Model" by Yasemin Boztuğ and Lutz Hildebrandt, May 2005.

029 "Utility Duality under Additional Information: Conditional Measures versus Filtration Enlargements" by Stefan Ankirchner, May 2005.

030 "The Shannon Information of Filtrations and the Additional Logarithmic Utility of Insiders" by Stefan Ankirchner, Steffen Dereich and Peter Imkeller, May 2005.

031 "Does Temporary Agency Work Provide a Stepping Stone to Regular Employment?" by Michael Kvasnicka, May 2005.

032 "Working Time as an Investment? - The Effects of Unpaid Overtime on Wages, Promotions and Layoffs" by Silke Anger, June 2005.

033 "Notes on an Endogenous Growth Model with two Capital Stocks II: The Stochastic Case" by Dirk Bethmann, June 2005.

034 "Skill Mismatch in Equilibrium Unemployment" by Ronald Bachmann, June 2005.

035 "Uncovered Interest Rate Parity and the Expectations Hypothesis of the Term Structure: Empirical Results for the U.S. and Europe" by Ralf Brüggemann and Helmut Lütkepohl, April 2005.

036 "Getting Used to Risks: Reference Dependence and Risk Inclusion" by Astrid Matthey, May 2005.

037 "New Evidence on the Puzzles. Results from Agnostic Identification on Monetary Policy and Exchange Rates." by Almuth Scholl and Harald Uhlig, July 2005.

038 "Discretisation of Stochastic Control Problems for Continuous Time Dynamics with Delay" by Markus Fischer and Markus Reiss, August 2005.

039 "What are the Effects of Fiscal Policy Shocks?" by Andrew Mountford and Harald Uhlig, July 2005.

040 "Optimal Sticky Prices under Rational Inattention" by Bartosz Maćkowiak and Mirko Wiederholt, July 2005.

041 "Fixed-Prize Tournaments versus First-Price Auctions in Innovation Contests" by Anja Schöttner, August 2005.

042 "Bank finance versus bond finance: what explains the differences between US and Europe?" by Fiorella De Fiore and Harald Uhlig, August 2005.

043 "On Local Times of Ranked Continuous Semimartingales; Application to Portfolio Generating Functions" by Raouf Ghomrasni, June 2005.

044 "A Software Framework for Data Based Analysis" by Markus Krätzig, August 2005.

045 "Labour Market Dynamics in Germany: Hirings, Separations, and Job-toJob Transitions over the Business Cycle" by Ronald Bachmann, September 2005.

\section{SFB 649, Spandauer Straße 1, D-10178 Berlin http:/ / sfb649.wiwi.hu-berlin.de}

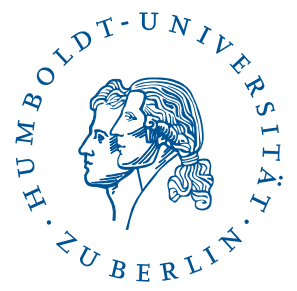


046 "Paternal Uncertainty and the Economics of Mating, Marriage, and Parental Investment in Children" by Dirk Bethmann and Michael Kvasnicka, September 2005.

047 "Estimation and Testing for Varying Coeffcients in Additive Models with Marginal Integration " by Lijian Yang, Byeong U. Park, Lan Xue and Wolfgang Härdle, September 2005.

048 "Zeitarbeit in Deutschland: Trends und Perspektiven" by Michael C. Burda and Michael Kvasnicka, September 2005.

049 "Courtesy and Idleness: Gender Differences in Team Work and Team Competition" by Radosveta Ivanova-Stenzel and Dorothea Kübler, September 2005.

050 "Do Factor Shares Reflect Technology?" by Benjamin Bental and Domonique Demougin, September 2005.

051 "Optimal investments for risk- and ambiguity-averse preferences: A duality approach" by Alexander Schied, September 2005.

052 "Relational Contracts and Job Design" by Anja Schöttner, September 2005.

053 "Explicit characterization of the super-replication strategy in financial markets with partial transaction costs" by Imen Bentahar and Bruno Bouchard, October 2005.

054 "Aid Effectiveness and Limited Enforceable Conditionality" by Almuth Scholl, August 2005.

055 "Limited Enforceable International Loans, International Risk Sharing and Trade" by Almuth Scholl, August 2005.

056 "Stock Markets and Business Cycle Comovement in Germany before World War I: Evidence from Spectral Analysis" by Albrecht Ritschl and Martin Uebele, November 2005.

057 "An empirical test of theories of price valuation using a semiparametric approach, reference prices, and accounting for heterogeneity" by Yasemin Boztuğ and Lutz Hildebrandt, November 2005.

058 "Integrable e-lements for Statistics Education" by Wolfgang Härdle, Sigbert Klinke and Uwe Ziegenhagen, December 2005.

059 "What does the Bank of Japan do to East Asia?" by Bartosz Maćkowiak, December 2005.

060 "Portfolio Value at Risk Based On Independent Components Analysis" by Ying Chen, Wolfgang Härdle and Vladimir Spokoiny, December 2005.

061 "How much of the Macroeconomic Variation in Eastern Europe is Attributable to External Shocks?" by Bartosz Maćkowiak, December 2005.

062 "The Impact of Industry Classification Schemes on Financial Research" by Christian Weiner, December 2005.

063 "The Conglomerate Discount in Germany and the Relationship to Corporate Governance" by Christian Weiner, December 2005.

\section{SFB 649, Spandauer Straße 1, D-10178 Berlin} http:/ / sfb649.wiwi.hu-berlin.de

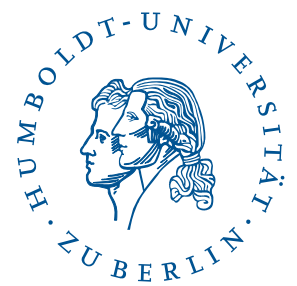

